\section{Estudo \\ Ecidebate}

em Testã⿻

Dlanejamento
Revista Estudo \& Debate, Lajeado, v. 27, n. 2, 2020. ISSN 1983-036X

DOI: http://dx.doi.org/10.22410/issn.1983-036X.v27i2a2020.2575

\title{
A DIMENSÁO PATRIMONIAL DA FLORESTA: UMA SÍNTESE HISTÓRICA
}

\author{
Denísia Martins Borba ${ }^{1}$, João Carlos Ferreira Melo Júnior ${ }^{2}$, Gerson Machado ${ }^{3}$
}

\begin{abstract}
Resumo: A pesquisa bibliográfica sobre a floresta atlântica, passando evolução conceitual de proteção do bioma ao longo da história do Brasil, bem como o olhar das comunidades de Candomblé sobre a floresta, visando resolver problemática: entendendo a floresta como território sagrado das comunidades de Candomblé, como se expressa a dimensão patrimonial da floresta a partir das percepçóes dessas comunidades? O objetivo da pesquisa foi investigar a percepção, que as comunidades de Candomblé têm sobre a floresta, bem como o conceito de floresta por parte dos gestores públicos buscam protegê-la desde a chegada dos portugueses em solo brasileiro até 2019. Destaca-se a importância de identificar o processo de patrimonialização da floresta e como as comunidades de Candomblé se relacionam com esse território, fundamental para sua prática de fé, destacando a importância da memória e da ancestralidade como fundamento dessas comunidades. A metodologia foi baseada na seleção da literatura científica disponibilizadas nas bases de dados EBSCO, Google Acadêmico, SciELO, Portal de Periódicos CAPES. Foram selecionadas, apenas as produçôes escritas em português, espanhol. Optouse pela busca booleana, usando os operadores "e" e "ou" para a combinação das palavras-chave nos dois idiomas da pesquisa. Como resultado apresenta-se um documento que sintetiza os movimentos de proteçáo da floresta ao longo da história brasileira. Conclui-se que, as políticas de proteção do patrimônio ambiental e cultural, no Brasil contemporâneo não mais se restringem ao âmbito do poder público, nem se esgotam na ação legal de tombamento ou dos inventários e registros em livros oficiais, mas é notável a ausência das comunidades de tradicionais na discussão e elaboração das políticas públicas na temática.
\end{abstract}

Palavras-chave: Floresta; candomblé; memória; patrimônio cultural e natural; patrimônio florestal; ancestralidade.

\section{THE PATRIMONIAL DIMENSION OF THE FOREST: A HISTORICAL SYNTHESIS}

\begin{abstract}
This work is the result of bibliographical research on the Atlantic Forest from conceptual evolution and its appropriation in Brazil as a colony, empire and republic; as well as the view of the Candomblé communities over the forest. The issue about the research is to investigate the perception and protection of the forest since the
\end{abstract}

1 Mestre em Patrimônio Cultural e Sociedade, Universidade da Regiáo de Joinville. Joinville/Santa Catarina.

2 Dr. em Ecologia e Conservação, Professor Titular do Programa de Pós-Graduação em Patrimônio Cultural e Sociedade, Universidade da Regiáo de Joinville, SC, Brasil.

3 Dr. em História, Museu Arqueológico do Sambaqui de Joinville/SC; Programa de Pós-Graduação em Memória Social e Bens Culturais, Universidade La Salle/Canoas/Rio Grande do Sul. 
arrival of the portuguese in Brazilian soil until 2019, seeking to understand the process of patrimonialization and how Candomblé communities relate to this territory, fundamental to their faith exercise, considering not only the importance of leaves for their rituals, but also because it is the Òrìsa habitat. The methodology was based on the selection of scientific literature available in the bibliographic databases such as Web of Science, Google Scholar, SciELO, CAPES Journals Portal, as well as academic papers available at repositories like Bank of Theses and Dissertations of brazilian universities. It was selected only productions written in portuguese and spanish. We opted for the Boolean search, using the "and" and "or" operators for the combination of keywords in the two research languages. As a result, is presented a document that synthesizes the forest protection movements throughout brazilian history. It is concluded that the protection policies of the cultural and environmental patrimony in contemporary Brazil are no longer restricted within the scope of public power, nor are they exhausted in the legal action of listing, or in inventories and records in official books.

Keywords: Forest; candomblé; memory; cultural and natural heritage; forest heritage; ancestrality.

\section{Introduçáo}

Esta revisão bibliográfica está associada à pesquisa "Árvores de Aguè Maré - florestas dos homens: um diálogo sobre o patrimônio florestal no território de Joinville", a qual teve como objetivo identificar, no município de Joinville, as áreas de remanescentes florestais da Mata Atlântica utilizadas como territórios culturais nos quais são realizados rituais do

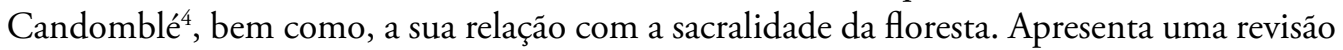
conceitual sobre a apropriação histórica e sua elevação à categoria de patrimônio cultural em perspectiva interdisciplinar. À esta pesquisa interessa os conceitos de floresta ao longo da história do Brasil, como se deu o processo de patrimonialização de territórios florestais ao longo dessa história, a utilização desses territórios pelas comunidades de Candomblé para a realização dos rituais e como essas comunidades tratam esses territórios que, a rigor, podem ser interpretados como patrimônio natural e cultural a partir da relaçáo sociedade-naturezaprática de fé.

O presente artigo é fruto de uma revisão bibliográfica que, não se ateve exclusivamente às florestas protegidas, tais como as Unidades de Conservação (UC) ou Áreas de Preservação Permanente (APP), ou seja, áreas geograficamente definidas com objetivo de proteger ecossistemas, mas sim, de áreas florestais utilizadas pelas comunidades de Candomblé para a realização de seus rituais e coleta de folhas, e que podem não ser oficialmente reconhecidas como patrimônio natural e cultural pelos instrumentos de reconhecimento e proteção oficiais do poder público.

O Candomblé configura uma sociedade oral que tem o continente africano como sua referência identitária e reconhece a fala não apenas como um meio de comunicação diária, mas também, como um meio de proteçáo da sabedoria dos ancestrais, envoltos em uma tradição que pode ser definida, de fato, como um testemunho transmitido oralmente de geração em geração. Essa prática cultural religiosa está presente em todo território brasileiro sob os mesmos valores e princípios da ancestralidade africana. Segundo Prandi (2004), o

4 Candomblé, religião estruturada no Brasil a partir das várias naçôes africanas que viveram a diáspora do século XVI. Segundo Lima (2003), nada permaneceu intacto nessa experiência de travessia África/Brasil. O que ocorreu foi uma reinterpretação e recriação dos simbolismos, dos mitos e dos ritos africanos em terras brasileiras. 
candomblé cultura Òrisà e outras divindades africanas tendo se constituído, inicialmente, na Bahia no século XIX e, há outras modalidades religiosas, também de matriz africana conhecidas por denominaçóes regionais, tais como Xangô, em Pernambuco, Tambor-demina, no Maranhão, e batuque, no Rio Grande do Sul. Essas organizaçóes culturais e religiosas são na diáspora formas de resistência cultural negra no Brasil.

\section{Material e Métodos}

Para a escrita deste artigo, optou-se pela metodologia de pesquisa bibliográfica, como proposto por Ferreira (2002), visando contribuir com o campo do conhecimento referente ao Candomblé, ao conceito de floresta e às políticas de proteção das florestas. Assim, realizou-se a pesquisa bibliográfica buscando destacar o conhecimento produzido sobre os temas apresentados, por meio de literatura e pesquisas já realizada por acadêmicos de diferentes áreas, bem como identificar quais são as fronteiras do conhecimento nas áreas do patrimônio cultural/natural e as comunidades de Candomblé. Nessa perspectiva obteve-se o levantamento sobre o estado atual dos conhecimentos sobre as temáticas citadas, sobre as mudanças conceituais ao longo da história do Brasil e sobre a contribuição da investigaçáo para o desenvolvimento do conhecimento como proposto por Romanowski \& Ens (2006).

Atualmente, as bases de dados digitais facilitam e simplificam essa tarefa, pois trazem recursos de busca e cruzamento de informaçóes, como sugere Oliveira (2008). Com uma visão geral sobre os temas especificados foi possível elaborar um roteiro para a revisão bibliográfica. As principais fontes consultadas para a elaboração da revisão bibliográfica foram artigos em periódicos científicos, livros, capítulos de livros, teses, anais de congresso, legislação nacional e sites governamentais e de organizaçóes não governamentais que se destacam no ativismo da proteçáo do patrimônio cultural/natural.

No âmbito da sistematização das informaçóes, foram utilizados como critérios para a seleção da literatura científica as publicaçôes disponibilizadas nas bases de dados bibliográficos, como EBSCO, Google Acadêmico, SciELO, Portal de Periódicos CAPES, assim como trabalhos acadêmicos disponíveis em repositórios do tipo Banco de Teses e Dissertaçôes de universidade brasileiras. Foram selecionadas as produçóes escritas em português e espanhol. Optou-se pela busca booleana, usando os operadores "e" e "ou" para a combinação das palavras-chave nos dois idiomas da pesquisa. As palavras-chaves utilizadas na pesquisa foram: floresta; Candomblé; memória; patrimônio cultural; patrimônio natural; ancestralidade, comunidades tradicionais de matriz africana; diáspora Africana. O período de seleção da literatura abrange desde o início do século XX até 2019, buscando responder ao problema da pesquisa: A revisão bibliográfica buscou responder ao problema da pesquisa: como se expressa a dimensão patrimonial da floresta a partir das percepçóes das comunidades de candomblé?

A pesquisa teve como recorte temporal os trabalhos publicados entre de 1918 e 2019, buscando identificar como o patrimônio natural brasileiro foi abordado no âmbito das políticas públicas durante esse período. Diante do foco da pesquisa não houve delimitação de categorias de publicações. Foram selecionadas 404 publicaçōes, as quais foram subdividas conforme sua natureza (Figura 1). 
Figura 1 - Natureza das publicaçôes científicas empregadas na revisão bibliográfica sobre a dimensão patrimonial da floresta numa perspectiva histórica.

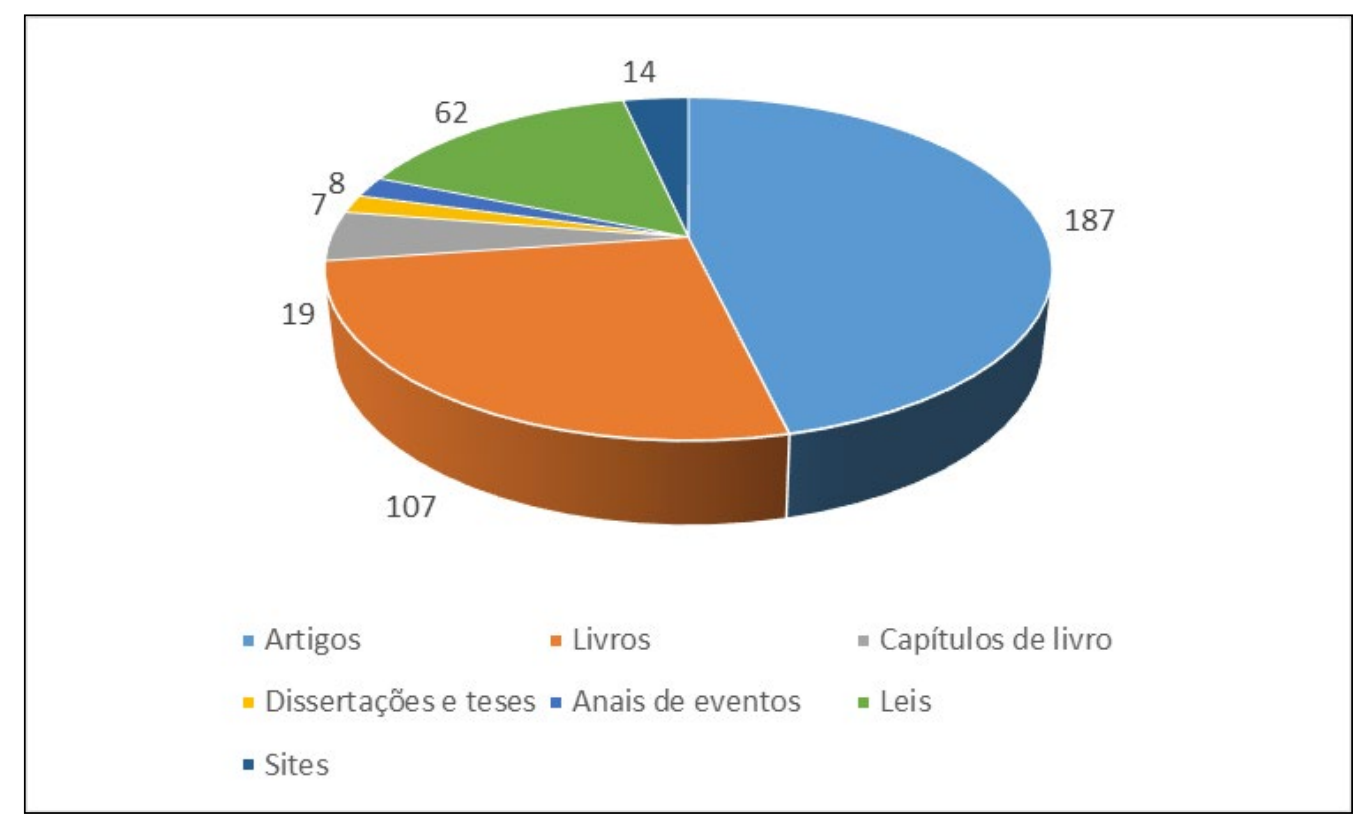

Fonte: primária, 2019.

A Figura 2 refere-se ao ano de publicação dos trabalhos, conforme as palavras-chaves utilizadas. Percebe-se que o número de publicaçóes a partir dos anos 2000 é crescente em relação aos anos anteriores, o que confirma a percepção quanto à atualidade das discussóes referente à temática da pesquisa. 
Figura 2 - Evolução do número de trabalhos encontrados nas bases de dados pesquisadas, divididos por palavras-chaves entre 1918 e 2019, sobre a dimensão patrimonial da floresta numa perspectiva histórica.

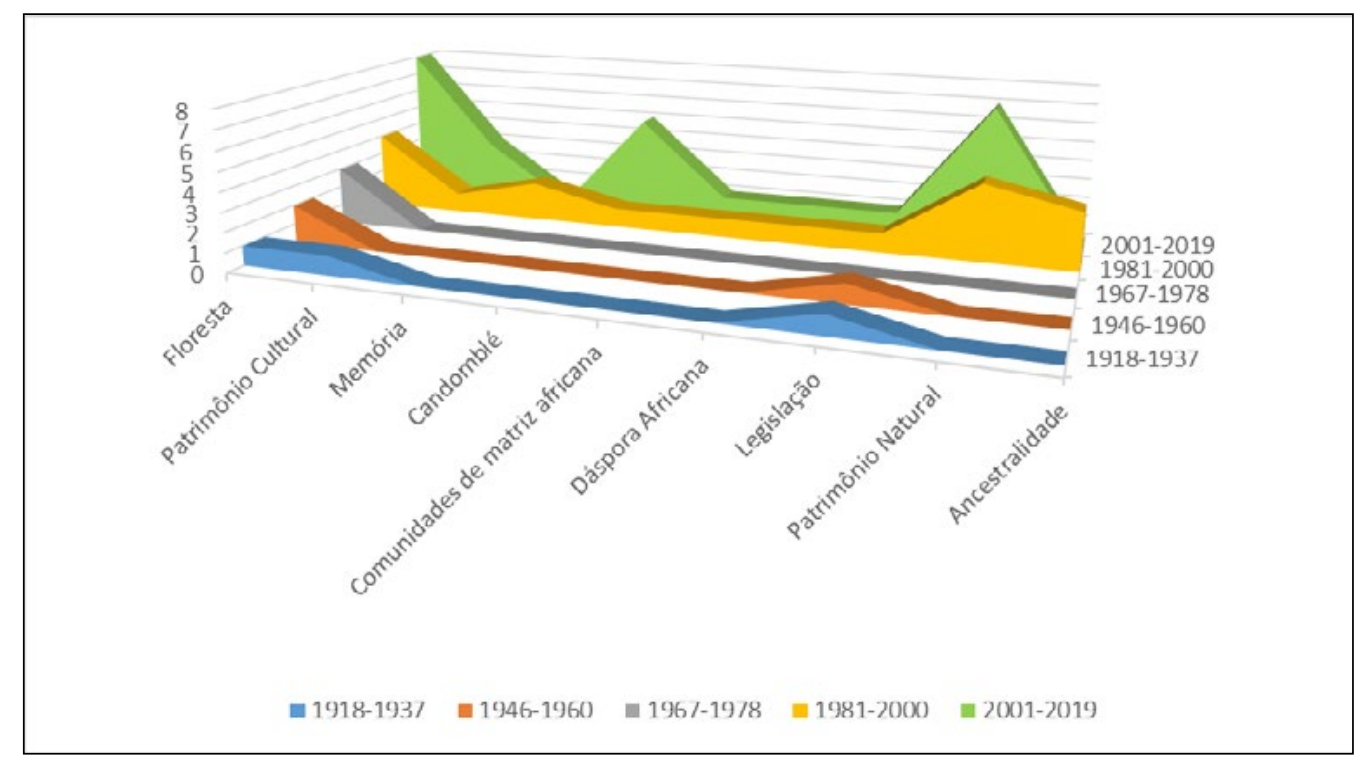

Fonte: primária, 2019.

A partir da pesquisa realizada nas bases de dados, selecionou-se o que melhor se adequava para responder ao problema da pesquisa. Assim foram selecionadas 138 publicaçóes, subdivididas em: 21 artigos, 38 livros, 05 capítulos de livros, 01 tese, 04 artigos publicaçóes em anais de eventos, 04 sites especializados e 04 legislaçóes.

A partir do levantamento bibliográfico foi possível analisar a produção acadêmica sobre a temática, buscando assim conhecer e agrupar as discussóes realizadas especialmente no Brasil, a partir dos temas mais recorrentes, os referenciais teóricos, as perspectivas apontadas e as contribuiçóes dessas produçōes para o campo do patrimônio cultural e natural e das realçóes de territorialidade da floresta nas perspectiva das comunidades de Candomblé, como um sub grupo das comunidades tradicionais de matriz africana. Assim, esta revisão bibliográfica possibilitou construir uma visão geral da evolução conceitual acerca do território florestal e da sua importância para as comunidades de Candomblé.

Observa-se, conforme apresentado na Figura 3, que a maior quantidade de publicaçóes encontradas nas bases de dados selecionadas, em relação às temáticas das pesquisas considerando as palavras chaves pesquisadas referem-se à floresta, seguida de patrimônio natural, Candomblé e patrimônio cultural. 
Figura 3 - Natureza temática das publicaçôes científicas selecionadas, conforme as palavraschave, na revisão bibliográfica sobre a dimensão patrimonial da floreste numa perspectiva histórica.

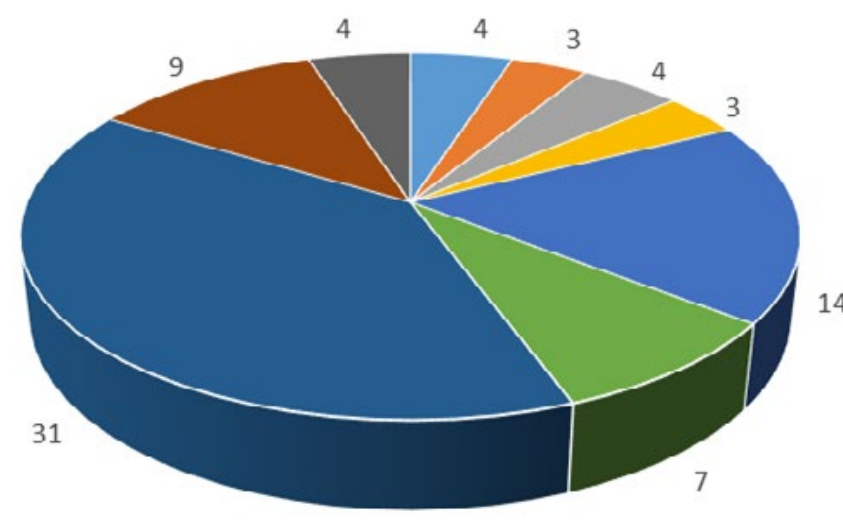

- L egislação

- Diáspora Africana

= Ancestralidade

- Comunidades tradicionais de matriz africana

- Patrimônio Natural

- Patrimônio cultural

- Floresta

- Candomblé

- Memória

Fonte: primária, 2019.

As publicaçôes pesquisadas e utilizadas nessa pesquisa estão categoria humanidades: história, ciências da religião e ciências sociais, ciências biológicas e políticas públicas, incluindo aquelas produzidas por órgão governamentais.

Destaca-se como dificuldades encontradas durante a pesquisa o fato de que os estudos semelhantes sobre a temática do Candomblé versam majoritariamente sobre os aspectos históricos, rituais, litúrgicos, memória e ancestralidade. Ainda há poucos trabalhos sobre o diálogo entre o Candomblé e os gestores públicos, no que diz respeito à floresta como território sagrado e como foco de disputas. 


\section{Resultados e Discussáo}

A partir da análise das publicaçóes encontradas e selecionadas foi construída uma análise sistematizada temporalmente sobre as políticas de proteção da floresta, desde a chegada dos portugueses em solo brasileiro, até o ano de 2019, passando pelas políticas de patrimonialização e sua importância para as práticas rituais das comunidades de Candomblé.

\subsection{Os conceitos de floresta e a origem das tramas sociais na Costa Atlântica}

São várias as definiçóes de floresta em uso, em âmbito nacional e internacional, e muitos países adotam diferentes definiçóes ao mesmo tempo. Optou-se aqui pela definição utilizada pelo Instituto Brasileiro de Geografia e Estatística (IBGE, 2012), que aproxima floresta ao conceito popular mata. Admitindo que, cientificamente, o termo é diversificado, adota o conceito como um conjunto de sinúsias ${ }^{5}$ dominado por fanerófitos ${ }^{6}$ de grande porte, com quatro estratos bem definidos (herbáceo, arbustivo, arvoreta/arbóreo baixo e arbóreo) ${ }^{7}$.

Dados do IBGE (2012), apontam que, as florestas podem ser classificadas como naturais ${ }^{8}$, plantadas ${ }^{9}$, homogêneas ${ }^{10}$, primárias $^{11}$, secundárias e ripárias ${ }^{12}$. As formaçóes florestais são motivadas por fatores distintos, entre os quais se destacam os padróes de latitude e longitude, altitude, clima, temperatura, regime de chuva, composição do solo e atividade humana.

5 Conjunto de plantas de estrutura semelhante, integrado por espécies com uma mesma forma de vida e necessidades ecológicas similares (IBGE, 2019).

6 São as espécies que apresentam gemas - gomos/brotos - vegetativas com alturas variando entre $25 \mathrm{~cm}$ e 50 $\mathrm{cm}$ de altura (IBGE, 2019).

7 Segundo definições do IBGE (2012) a altura é o que a diferencia das outras formaçóes lenhosas campestres. Na floresta, há dominância de duas subformas de vida de fanerófitos como macrofanerófitos, com alturas que variam de $30 \mathrm{~m}$ a $50 \mathrm{~m}$, e mesofanerófitos, com variaçóes entre $20 \mathrm{~m}$ a $30 \mathrm{~m}$ de altura. Outra característica é o adensamento das grandes árvores, que limitam a incidência de luz que atinge o solo, o que define o desenvolvimento das sinúsias na forma de herbáceas e arbustivas. Dessa forma, mata, mato, bosque, capoeira e selva são algumas das terminologias que designam a floresta, inclusive a Atlântica.

8 Conforme dados do IBGE (2012) são florestas naturais os exemplares que se encontrarem no seu estado original e não sofreram impactos de intervenção humana.

9 As florestas plantadas, segundo IBGE (2012) compóem o grupo daquelas que foram intencionalmente produzidas pelo homem com objetivos específicos, sejam eles a produzir de recursos ou recuperar áreas anteriormente devastadas.

10 As florestas homogêneas, segundo IBGE (2012) são aquelas constituídas por poucas espécies arbóreas.

11 O IBGE (2012) considera Florestas primárias aquelas originais e/ou típicas de uma região que não sofreram derrubadas e/ou equivalentes. Os exemplares que estão em processo de reestruturação natural depois de derrubadas ou alteraçôes pela ação do homem ou de fatores naturais são classificados como secundárias.

12 Cf. IBGE (2012) as florestas ripárias/matas ciliares são aquelas que ocupam uma ou as duas margens de um curso d'água. 
Segundo a Organização das Nações Unidas (ONU), para a agricultura e alimentação - FAO (2019), os aspectos de uso e ocupação do solo são importantes para se definir floresta $^{13}$, dos quais se excluem os territórios nos quais haja predominância de atividades agrícolas ou estejam no perímetro urbano. A Convenção das Naçóes Unidas sobre Mudanças Climáticas $^{14}$ - UNFCC (2019) apresenta uma definição similar para o conceito de floresta, acrescentando as mudanças climáticas. Contribui para a discussão Gonçalves (1990), apresentando definiçóes para povoamentos naturais jovens, bem como todas as plantaçóes que têm capacidade de atingir a uma densidade entre $10 \%$ e $30 \%$ ou a uma altura entre $2 \mathrm{~m}$ e $5 \mathrm{~m}$ são incluídos como floresta, assim como as porçóes de terra, que fazem normalmente parte de áreas de florestas e são temporariamente desflorestadas resultantes de intervençóes humanas (por exemplo, para plantio) ou de causas naturais, mas cuja resiliência é efetivamente possível. Soma-se, assim, ao conceito adotado pela bioecologia dado à floresta a concepção de natureza, muitas vezes como ideia análoga, e a dimensão social relacionada ao uso e as formas de apropriaçáo pelo ser humano.

A relação entre sociedade e natureza veio sendo transformada ao longo do tempo, desde o domínio da forja de ferramentas que serviriam à agricultura contribuído para essa mudança (Diegues, 2008). Desde entáo, a natureza foi ocupada e cotidianamente transformada pelo homem. As primeiras organizaçóes sociais, constituídas em aldeias, tinham como principal atividade a agricultura, que ocupava grandes áreas dispostas no entorno das moradias e acompanhando o curso dos rios. Ainda segundo o autor, o que excedia era armazenado para o consumo entre uma colheita e outra e havia, também, o escambo entre comunidades que produziam mercadorias diferentes.

A cidade e os campos agrícolas, durante séculos são resultado da dominação da natureza pelo homem. Segundo Cabral (2014), o homem estava familiarizado com seus habitantes, animais e plantas nesse espaço, bem como com suas transformações naturais ocasionadas, por exemplo, pelas cheias dos rios e a sequência das estaçóes. Fora desses limites, da natureza transformada por açóes humanas, parcialmente ordenada e conhecida, estava o caos, o mundo selvagem, o que sugeria perigo, porque ainda não havia sofrido intervenção humana. A natureza era selvagem, contraposta à natureza humanizada.

O meio ambiente, interpretado na visão humanizada, na qual o homem está presente e intervindo e não-humanizado, entendido como territórios que o homem ainda não havia alcançado, foi conceituação dominante ao longo de séculos de história, assumindo diversas formas. Em síntese uma natureza infinita, conforme destaca Roncáglio (2009). Ainda

13 Conforme a Food and Agriculture Organization/FAO (2019), Agência da Organização das Naçôes Unidas para a Alimentação e a Agricultura medida do terreno acima de 0,5 ha, com a presença de árvores com altura superior a $5 \mathrm{~m}$ e cobertura de copa superior a $10 \%$, ou a presença de árvores capazes de alcançar estes parâmetros.

14 O conceito de floresta é uma área mínima de terra de 0,05 ha a 1,0ha, com cobertura arbórea (ou densidade equivalente) entre $10 \%$ e $30 \%$ e com árvores que apresentem potencial para atingir uma altura entre $2 \mathrm{~m}$ a 5 m na maturidade. Segundo Gonçalves (1990), as formaçôes florestais podem ser classificadas como fechadas/densas, em que árvores de vários estratos e do sub-bosque ocupam grande extensão de solo, ou podem ser dispersas, com menor ocupação do solo. 
conforme a autora, com as descobertas ocorridas no período das navegaçôes, no século XVI, e com os avanços da Ciência e da crítica filosófica, muda-se o conceito sobre a natureza não-humana, retirando dela o aspecto sobrenatural, construído pelo imaginário popular. Ao final do processo das mudanças de percepção sobre a floresta de forma mais acentuada no início do século XIX, a natureza selvagem e desconhecida foi deixando de inspirar medo e de ser vista como espaço supranatural para despertar o interesse pelos recursos naturais disponíveis.

Junto à mudança conceitual sobre a natureza se dá o surgimento de um novo modelo econômico - o capitalismo - o desenvolvimento tecnológico, da indústria e dos transportes e de grande número de descobertas científicas, com a promessa de que o progresso beneficiaria todas as terras, mesmo aquelas mais distantes e selvagens ${ }^{15}$.

Durante os séculos XV e XVI, os exploradores europeus, em especial os portugueses e espanhóis, deram início às grandes navegaçōes. Partiram pelos oceanos Atlântico, Pacífico e Índico rumo ao desconhecido, o que posteriormente ficou conhecido, conforme aponta Boxer (2002) como a Era das Navegaçóes e Descobrimentos Marítimos ${ }^{16}$. Os portugueses, insatisfeitos com o monopólio de especiarias indianas por parte de Gênova e Veneza, buscaram novas terras conforme ressalta Cabral (2014) explorar matéria prima, metais preciosos e produtos inexistentes no continente europeu para que pudessem fazer frente ao mercado internacional. À Igreja Católica também interessava tais descobertas pela possibilidade de agregar novos fiéis.

Durante o reconhecimento do solo brasileiro pelos integrantes da Caravela de Cabral, não era, a princípio, os seus habitantes o que verdadeiramente chamava a atenção dos expedicionários, mas a probabilidade de haver metais e pedras preciosas. Também não se interessavam pelo tipo de solo, pois Portugal ainda náo pretendia ocupar o território brasileiro, tampouco desenvolver a agricultura. Os portugueses vinham ao novo mundo (colônias) em busca de riqueza, mas a riqueza que necessitava de trabalho longo e permanente. Essa era a motivação que os movia para alcançar a Índia, seu interesse era por

15 Segundo Cabral (2014) as florestas na América do Sul, cederam espaço às ferrovias para melhorar os transportes que deveriam trazer riquezas para a regiáo.

16 Conforme destaca Cabral (2014) a experiência dos portugueses em navegaçóes, que dominavam a prática da pesca, foi um dos fatores favoráveis àquele país. As caravelas desenvolvidas por Portugal eram o principal meio de transporte marítimo e comercial do período, de categoria elevada se comparada à de outras naçôes. Ainda segundo o autor as caravelas eram utilizadas para transportar grande quantidade de mercadorias, bem como pessoas. A chegada de Cabral em terras brasileiras em abril de 1500 e, em seguida, às Índias, fez de Portugal a principal potência econômica da época. 
especiarias e os metais preciosos como aponta Holanda (1995). Encontraram, em terras brasileiras, florestas diferentes daquelas que, até então, conheciam ${ }^{17}$.

O escrivão oficial, Pero Vaz de Caminha descreveu detalhadamente a terra em que aportou a comitiva de Cabral em sua carta ao rei de Portugal, com admiração apreço que a nova terra e sua paisagem causaram ${ }^{18}$.

Quando os portugueses desembarcaram em solo brasileiro, a Mata Atlântica ocupava mais de um milhão de $\mathrm{km}^{2}, 12 \%$ do atual território brasileiro, o que "abrangia total ou parcialmente 17 Estados brasileiros ${ }^{19}$.

Os portugueses encararam a floresta vultuosa como um sinal de fertilidade do solo brasileiro, mas a fecundidade era apenas superficial, desencadeada pela rápida ciclagem dos minerais do solo à medida que plantas e animais se decompunham e não como uma característica natural da terra conforme apresenta Cardim (1939). Esse pensamento pode ser confirmado na obra de Salvador (1918), quando esse descreve as grandes e belas árvores que produziam madeira de qualidade, de beleza e de cores diversas, capazes inclusive de fornecer tinta. Pero Vaz de Caminha, segundo Cortesão (1967) não tinha a dimensão da realidade sobre o território brasileiro, quando o descreveu, em sua famosa correspondência ao rei de Portugal, que qualquer tipo de plantio floresceria.

A Mata Atlântica, conforme ressalta Dean (1996), sofreu as primeiras açóes de desflorestação assim que os primeiros colonizadores chegaram ao Brasil. A primeira árvore cortada em 1500 foi para montar a cruz da primeira missa. Essa ação era o prenúncio da devastação que se seguiria com o extrativismo. O pau-brasil ou pau-de-tinta (Caesalpinia

17 Segundo Cabral (2014), quando os portugueses chegaram em solo brasileiro puderam ver árvores de tamanho distintos e que a elas se misturavam flores, cipós, samambaias, arbustos e uma infinidade de ervas espalhadas por um solo úmido coberto por raízes e mudas, não deixando praticamente nada à vista. A floresta, conforme destaca Cabral (2014) era uma área escura, devido à cobertura cerrada de folhas, galhos e flores, o que dificultava a incidência solar. Naquele período, os portugueses avaliavam que as terras brasileiras eram de dimensóes incalculáveis e, portanto, pensar na finitude da floresta era impossível.

18 O conteúdo da Carta foi minuciosamente analisado por Cortesão (1967), o primeiro e um dos mais famosos documentos produzidos no Brasil e sobre o Brasil destaca as belezas naturais encontradas pelos portugueses.

19 Segundo Schaffer \& Prochnow (2002), a mata atlântica é bioma dos seguintes estados: RS, SC, PR, SP, GO, RJ, MG, ES, BA, AL, SE, PB, PE, RN, CE, PI), situados ao longo da costa atlântica, do Rio Grande do Sul ao Rio Grande do Norte, além dos Estados de Mato Grosso do Sul e Goiás" (SCHAFFER \& PROCHNOW, 2002, p. 13). 
echinata Lam - Fabaceae) ${ }^{20}$, encontrado em solo brasileiro é uma árvore nativa e, à época, abundante no e servia como matéria prima para o tingimento de tecidos ${ }^{21}$.

A história das políticas públicas referentes às florestas no Brasil, como destaca Ioris (1994) apresenta um quadro contínuo de desmatamento desde o período do descobrimento, passando por modelos que variaram entre os autoritários e burocráticos aos mais democráticos e participativos, tentando se adequar às políticas internacionais. Na maioria das vezes, problemas sociais e ambientais são o resultado de modelos econômicos baseados no imediatismo, pautados no lucro e na falta de compromisso com o meio ambiente.

A diversidade vegetal encontrada era surpreendente quando os portugueses se viram diante da Mata Atlântica ${ }^{22}$. Segundo ressalta Léry (1972), as epifitas ${ }^{23}$ eram desconhecidas dos europeus até então, que encontravam, em uma única árvore, dezenas de orquídeas de espécies diferentes, considerando que no continente europeu, as árvores apresentavam apenas camadas finas de líquens e musgos.

Quando começaram a registrar as espécies vegetais existentes na Mata Atlântica, os europeus pensavam que seria impossível a catalogação completa ${ }^{24}$. Roncáglio (2009) ressalta que, centenas de espécies foram registradas por pesquisadores anônimos, e no século XIX uma nova onda de interesse ocorreu, quando o barão russo Langsdorff ${ }^{25}$ liderou uma nova expedição.

20 As árvores de pau-brasil, com cerca de $20 \mathrm{~m}$ de altura, distribuíam-se em abundância por todo o litoral. Segundo Couto (1997), a ausência de planejamento para a exploração fez com que, em um século, cerca de 2 milhóes de árvores já tivessem sido derrubadas. Os povos originários brasileiros demoravam, em média, três horas para derrubar uma árvore usando ferramentas rudimentares (na maioria de pedra). Após a introdução do machado de ferro dos europeus, gastavam apenas 15 minutos. No século XXI, o pau-brasil, árvore típica da Mata Atlântica está restrita a poucos trechos.

21 Como ressalta Dean (1996) assim, a exploração de madeira, o cultivo da cana-de-açúcar, em especial no Nordeste, e o desenvolvimento de centros urbanos ao longo do litoral reduziram, em pouco mais de 500 anos, a $6 \%$ as áreas de florestas primárias quase intactas durante aproximadamente 10.000 anos na América do Sul.

22 Segundo Roncáglio (2009), encontraram incontáveis flores e folhas brotavam em um único tronco, tais como bromélias, orquídeas e samambaias eram como microflorestas, que surgiam em cada árvore.

23 Conforme define Lery (1972) tipo de vegetação que cresce sobre outras em busca de luz, mas que obtém água e nutrientes de forma independente, não sendo consideradas parasitas porque não prejudicam as hospedeiras.

24 Segundo Roncáglio (2009), a primeira leva de viajantes documentaristas, como ressalta atendeu ao convite do príncipe Maurício de Nassau, o governador do estado do Pernambuco, no período da ocupação holandesa no período entre 1637 e 1644.

25 Roncáglio (2009) apresenta que, entre os artistas do grupo, destacaram-se o belga Johann Moritz Rugendas e os franceses Aimé-Adrien Taunay e Hercules Florence. 


\subsection{As florestas nacionais no Brasil Colônia}

A preocupação para com as florestas brasileiras no período colonial era de que elas abastecessem o mercado europeu com a substância vermelha extraída do pau-brasil ${ }^{26}$.

Não foi a chegada dos portugueses em solo brasileiro que garantiu a sua permanência. Foi só a partir de 1531, com a ascensão de D. João III, que a política para as colônias portuguesas mudou. O principal marco na formação da grande propriedade agrícola brasileiras, segundo Dean (1996) e deu por meio do sistema de capitanias hereditárias ${ }^{27}$, o sistema administrativo colonial adotado pela Coroa portuguesa no Brasil.

A economia brasileira pode ser interpretada por ciclos que vão sempre interferir diretamente na proteção das florestas. O primeiro ciclo, o do extrativismo, durou de 1500 a 1534, e foi o pau-brasil a árvore mais explorada e exportada. A partir de 1534, teve início o primeiro ciclo de monocultura no Brasil, com o plantio da cana-de-açúcar em escala industrial ${ }^{28}$.

O sistema de Sesmaria, como ressalta Diniz (2005) pode ser entendido como uma subdivisão da Capitania, objetivando o melhor aproveitamento das terras. O primeiro donatário tinha como direito a redistribuição das terras recebidas de forma a atender os seus interesses. No Brasil, Martim Afonso de Souza foi o primeiro donatário autorizado pela Coroa, em 1532, a distribuir terras, cuja carta-patente ${ }^{29}$ pode ter sido o primeiro documento oficial de distribuição de terras do Brasil. O sistema de capitanias hereditárias não foi completamente bem-sucedido, com exceção das capitanias de Pernambuco e São

26 Utilizada como corante, e ainda mantivessem o estoque de madeira da metrópole portuguesa para diversas finalidades, como a construção civil e embarcaçôes (Hutter, 1986; Lima et. al., 2017); como fonte de energia para as máquinas que estavam em franco desenvolvimento e, especialmente, para a extração de lenha, usada em fogóes e aquecedores. Entretanto, de acordo com Dean (1996), as maiores ameaças à manutenção das florestas foram as lavouras de cana-de-açúcar, entre os séculos XVI e XVIII, e o plantio de café, que teve seu período áureo entre 1800 e 1930.

27 Esse sistema, segundo Diniz (2005) controlava o uso da água e a exploração de recursos minerais e de madeiras, em especial do pau-brasil, que muito interessava à Europa por suas finalidades variadas. Quando as políticas de ocupaçáo territorial se efetivaram, a partir de 1530, o governo português decidiu operar mudanças no sistema das Sesmarias no Brasil, com objetivo e ocupar a nova terra com pequenos investimentos por parte da Coroa Portuguesa. Ainda segundo o autor com a adoção do sistema de capitanias, os investimentos seriam por conta dos favorecidos com a doação de terras.

28 Segundo Mello (2012) a primeira atividade economicamente contínua da agricultura no Brasil se deu com os engenhos e por volta de 1540, havia trinta engenhos em Pernambuco, dezoito na Bahia e dois em São Vicente, contudo em pouco mais de cinquenta anos, o número de engenhos concentrados na produção do açúcar era superior a 250 .

29 Cf, Diniz (2005). Cartas-patente são documentos legais em forma de carta aberta, entregues por um representante governamental, que garante ofício, direito e/ou monopólio. 
Vicente, que se desenvolveram de acordo com as expectativas portuguesas ${ }^{30}$. O sistema sesmarial de terras foi a política da coroa portuguesa para o Brasil ${ }^{31}$ até meados de 1822 , como apresenta Magalhães (2002), quando a Resolução no 76, de autoria atribuída a José Bonifácio de Andrade e Silva, suspendeu concessóes até a convocação da Assembleia Geral Constituinte ${ }^{32}$.

O Monarca, Felipe II, de origem espanhola chegou ao poder em 1595 e inaugurou uma nova legislação, que contava com novos princípios que resultaram nas Ordenaçóes Filipinas, o que prevaleceu em Portugal entre 1603 e 1867, no Brasil, segundo Milaré (2001) o ato normativo prevaleceu até $1916^{33}$.

Algumas açóes foram adotadas com o objetivo de proteger as florestas pelo Rei Dom João VI, logo após a fixação da corte portuguesa no Brasil, em 1808, como a criação do Jardim Botânico, no Rio de Janeiro ${ }^{34}$.

A exploração do pau-brasil, de forma legal ou não, foi uma atividade intensa no início do período colonial ${ }^{35}$. Conforme apresenta Dean (1996) visando combater essa atividade,

30 Segundo Diniz (2005) foi estabelecido, nas primeiras capitanias, o cultivo de cana-de-açúcar e instalaçáo de engenho e, apesar de enfrentarem problemas existentes em várias capitanias, vários donatários conseguiram manter seus colonos em suas propriedades, além de estabelecer alianças com os indígenas. $\mathrm{O}$ restante das capitanias enfrentou problemas de manutenção e/ou dificuldades em encontrar interessados em assumir as capitanias disponibilizadas pela cora.

31 Pádua (1987) destaca que era praticado o método de corte e queimadas da floresta, buscando limpar e fertilizar a área, prática o que resultava na expansão das propriedades, em busca de terras mais apropriadas ao cultivo agrícola. Para que essa expansão fosse legal, era necessário solicitar formalmente à Coroa Portuguesa. Portanto, nesse modelo agrícola, observa-se que o Período Colonial se baseou na expansão da fronteira agrícola sobre a floresta/vegetação natural.

32 Posteriormente, a Lei Imperial no 601/1850 regulou o regime de terras, indicando o direito privado por ocupação primária.

33 Como destaca Wainer (1991), em 1605, essa normativa, esteve em vigor até 1859 foi instituída por Felipe II o "Regimento do Pau-brasil", na qual foi estabelecido que a exploração da referida árvore poderia atingir o máximo de 600 toneladas ao ano. O objetivo da normativa era regular a oferta de madeira no mercado europeu de forma a manter preços satisfatórios.

34 Segundo Magalháes (2202) o objetivo do Jardim Botânico era promover a adaptaçáo de plantas diversas, inclusive especiarias de origem da Índia. Em 1809, outra ação de Dom João VI que pode ser destacada foi a promulgação da lei que libertava escravos, contudo, essa liberdade era concedida apenas àqueles que se como denunciantes de infraçôes cometidas contra o meio ambiente. Ainda segundo o autor, mesmo com o domínio do corte, plantio e comercialização do pau-brasil, o Estado não se mostrou eficiente no combate à exploração predatória, o que causou a quase extinção da espécie. Em 1826, sua escassez já era observada, fazendo Portugal buscar alternativas para sua proteçáo, tais como determinar à Junta da Fazenda Pública de Pernambuco a reprodução de árvores da espécie, em uma tentativa de evitar a falta da madeira no mercado europeu.

35 A proteção ambiental ainda não era fonte preocupação e predominava o caráter utilitarista e predatório por parte das oligarquias rurais, que não utilizaram nenhuma técnica capaz de evitar o desgaste e o empobrecimento do solo. Tal prática, segundo Wainer (1991) pode ter sido adotada porque, naquele período, acreditava-se que os recursos naturais eram inesgotáveis. 
em $1534^{36}$, a Coroa, admitindo a dificuldade de combater os concorrentes estrangeiros, decretou que as respectivas árvores eram de propriedade real, sendo, para sua derrubada, necessária a concessão governamental. Tal medida esteve em vigor por três séculos.

Por volta de 1713, constatando-se frequentes períodos de seca, começou-se a associálas aos desmatamentos que visavam à expansão da agricultura. Objetivando contê-los, o governo publicou uma série de decretos, especialmente a partir da grande seca que aconteceu entre os anos de 1791-1792 ${ }^{37}$. Durante o período da exploração do ouro na região Sudeste — também de forma devastadora —, a agricultura começou a enfrentar o seu declínio no Nordeste. Diante dessa realidade, como forma de contornar a crise, a Coroa decidiu mudar a capital da colônia de Salvador para o Rio de Janeiro, buscando aproximar a capital do novo polo de desenvolvimento econômico: a exploração aurífera. Nas regióes auríferas, vários centros urbanos cresceram ${ }^{38}$ e outros tantos surgiram buscando atender às demandas dos garimpeiros e dos altos cargos da coroa portuguesa.

\subsection{A política ambiental no Brasil Império}

Durante o século XIX, o Brasil recebeu um sem número de expedições de cientistas de diferentes áreas do conhecimento e artistas para identificar e registrar a fauna e flora do país. Cada regiáo recebeu diversos e diferentes grupos de estudos com esses objetivos ${ }^{39}$.

Os conceitos de meio ambiente, conforme ressalta Roncáglio (2009) mudaram: admiração, medo e busca por dominação presentes quando chegaram cederam espaço à ciência no final do século XVIII e início do Século $\mathrm{XX}^{40}$.

36 O pau-brasil era utilizado intensamente pelos indígenas brasileiros que, da madeira extraída confeccionavam seus arcos, flechas e do corante produziam as pinturas corporais e de seus adereços. Foram os indígenas que ensinaram aos portugueses a técnica para se extrair o corante do cerne da árvore e esses desenvolveram o comércio internacional marcante até o descobrimento de outros corantes, como as anilinas e a oferta de outras madeiras.

37 Segundo Bursztyn (2012) nesse período, estabelece-se categórico controle ao desmatamento, o que culminou com a criaçáo do serviço de conservaçáo florestal em 1796, controlado por um juiz.

38 Segundo Cortesão (1967) a vida nas cidades ganhou uma nova dinâmica, com o aparecimento de novas profissões e a intensificação de atividades comerciais.

39 Destacam-se entre o grupo, Johann Baptist Von Spix (zoólogo), Karl Friedrich Phillip von Martius (botânico), Thomas Ender, Johann Buchberger, Franz Joseph Frühbeck e Frick (pintores), Ferdinand Dominik Sochor (caçador e preparador), Heirinch Wilhelm Schott (jardineiro), Rochus Achüch, Johann Natterer, Giuseppe Raddi, Johann Emanuel Pohl, Johann Christian Mikan (naturalistas), Alexander von Humboldt, Auguste Saint-Hilaire, Friedrich Salathé e Alexandre Rodrigues Ferreira eram os mais conhecidos, no Brasil e no exterior, pela realização de exposiçôes e publicaçôes de suas pinturas, gravuras e as descriçóes minuciosas sobre a meio ambiente e os costumes da populaçáo que vivia no Brasil entre os séculos XVIII e XIX.

40 Ainda segundo Roncáglio (2009), o objetivo das expedições de cientistas internacionais era pesquisar a fauna e a flora, na maior extensão possível, e o comportamento dos habitantes seria minuciosamente observado e registrado, bem como suas práticas sociais, políticas, econômicas, culturais, lazer, diversão, transportes, administração pública, práticas religiosas e, também a geologia e, as variaçôes climáticas. 
Entre 1860 e 1900, na Europa, a Revolução Industrial estava em franco desenvolvimento. $\mathrm{O}$ aço era a matéria prima imprescindível na indústria, assim como a energia elétrica ${ }^{41}$. Já no Brasil, segundo Diegues Jr. (1960), grandes transformaçóes ocorreram durante o período imperial e este fenômeno, afetou os setores econômico e social, impactando o meio ambiente ${ }^{42}$.

O mundo agrícola, segundo Feldens (2018) se deparou com diversos modelos, desde a antiguidade até os dias atuais. Importante perceber o grau de investimento na produção e na tecnologia empregada no cultivo ou na criaçáo de animais, assim como o índice de produtividade, modelo em que se espera que a natureza produza conforme seu potencial natural, ou aquele em que haja a intervenção humana buscando proporcionar uma produção que atenda às necessidades da população.

Segundo Wainer (1991) a primeira normativa de proteção ambiental foi a Ordenação apresentada pelo Rei D. Afonso IV, em 1393, e posteriormente escrita no Livro V, Título LVIIII, das Ordenaçóes Afonsinas ${ }^{43}$. A partir de 1821, segundo Cabral (2014) outra legislação foi apresentada sobre manutenção das florestas e o uso da terra, decretando que em um sexto das florestas deveriam ser mantidas nas áreas vendidas ou doadas. Em 1850, os proprietários de terras, segundo Antunes (2000) pressionaram o governo para que a não houvesse listagem de madeiras de uso restrito da Coroa portuguesa. A Coroa apresenta a Lei $\mathrm{n}^{\circ}$ 601, de 18 de setembro de $1850^{44}$. Desde então, a terra assume a categoria de mercadoria, acessível a quem pudesse comprá-la.

O Decreto n 4.887 de $1872^{45}$, criou a Companhia Florestal Paranaense, na Província do Paraná, no município de Borda de Campo, onde, segundo Pereira (1950) foi montada uma fábrica a vapor para serrar pinho ${ }^{46}$.

41 Segundo Beaud (1989), os combustíveis e derivados do petróleo se popularizam, enquanto a invenção do motor à explosão e da locomotiva a vapor e o desenvolvimento de produtos químicos foram inovaçôes desse período.

42 As soluções que fenômenos como a Revolução Industrial ofereceram ao homem também apresentaram impactos, tanto nas relaçôes sociais, como na relação com a natureza.

43 Segundo Feldens (2018), as Ordenaçôes Afonsinas proibiam o corte deliberado de árvores frutíferas, classificado como calúnia ao rei.

44 Conhecida como Lei de Terras, como aponta Séguin \& Carrera (1999) passa a definir que a aquisição de terras se daria por meio de compra, e o usucapiáo sobre terras públicas a partir daquele momento seria considerado crime.

45 Decreto assinado pela regente no período, a Princesa Izabel, estabeleceu o início da atividade florestal particular, autorizando o comércio legal de madeiras.

46 Segundo Pereira (1950), essa atividade foi passageira porque, não havia transporte para o escoamento da madeira. 


\subsection{As florestas do Brasil Republicano}

No período colonial brasileiro, os recursos naturais eram controlados por meio de normas e instituiçóes sob o controle do Estado, que se baseia justamente no sistema de titularidade jurídica de propriedade estatal com a concessáo de uso e a adoçáo de instrumentos econômicos, tais como o estabelecimento de taxas, de impostos e a prática de fiscalização de forma rígida, com aplicação de penalidades caso fosse verificada a infração das regras estabelecidas, caracterizando um sistema de comando e controle.

Nas primeiras décadas do período republicano, a questão ambiental ainda não era alvo de preocupaçóes por parte do governo brasileiro ${ }^{47}$. Desta forma, entendeu-se, segundo Pereira (1950), ser desnecessário que a legislação federal ${ }^{48}$ se ocupasse da temática.

Em 1920, a questão florestal passou a contar com legislação específica para a sua gestão por parte do governo federal ${ }^{49}$. A retomada do controle sobre a terra se deu durante o governo de Getúlio Vargas (1930-1945), com a promulgação da Lei do Direito de Água no Brasil (Código das Águas), segundo Rebouças (1976), assim como os códigos florestal e de mineração ${ }^{50}$. Um exemplo de alteração na Constituição Federal de 1934, foi preconizado no Cap. II - Dos Direitos e das Garantias Individuais - art. 113, item 17²1. É também de 1934 o primeiro Código Florestal brasileiro. Tal legislação, segundo Ioris (2014) se apresenta como instrumento de controle com objetivos de impactar o menos possível os efeitos das açôes do homem sobre o meio ambiente.

A Constituição Federal de 1946 (BRASIL, 2019) acrescentou o conceito de que a terra deveria cumprir função social ${ }^{52}$, prevendo o controle dos usos dos recursos naturais e a proteção do meio ambiente.

47 A Constituição republicana de 1891 não apresentou nenhum artigo relativo à proteção das florestas ou de alguma árvore específica. Por meio dela, foi transferido aos estados o domínio das terras devolutas, que compreendiam as áreas florestais.

48 Segundo Ioris (2014) o conceito liberal para o direito de propriedade, presente no artigo 72 , $\$ 17$ da Constituição Federal de 1934, impossibilitava iniciativas que limitassem o uso de florestas particulares, atribuindo-lhe o caráter de bem público.

49 Naquele ano, o Presidente Epitácio Pessoa criou uma subcomissão que deveria elaborar um anteprojeto de lei, que foi transformado em Decreto presidencial no 23.793, de 1934 e que, como ressalta Ahrens (2003) se popularizou como Código Florestal. O Decreto foi uma inovaçáo impondo limites no direito de uso da propriedade privada, determinando, segundo Dean (1996) que, $25 \%$ da vegetaçáo nativa de cada propriedade rural deveria ser preservada. Em 1965, esse Código foi revisto e transformado na Lei no 4.771, vigente até 2012, quando foi novamente revisto e substituído na Lei no $12.651 / 12$.

50 Mesmo que estivessem previstos ganhos sociais, o Estado Novo náo implementou vários indicativos constitucionais.

51 Autoriza a desapropriação de terras de interesse público mediante indenização.

52 Considera-se que, a terra pode ser de propriedade privada e deve ser utilizada de forma a garantir a subsistência do homem e, suas geraçóes. 
Acompanhando a legislação federal brasileira desde o período da colônia, observamos que são da era Vargas as primeiras tentativas do Estado para controlar o uso dos recursos naturais ${ }^{53}$. A criação dos Códigos Florestal, de água, de minas, da caça e pesca e a realização da Primeira Conferência Brasileira de Proteção à Natureza ${ }^{54} \mathrm{em} 1934$ foram, segundo Lustosa et al. (2003) iniciativas de destaque do Governo Vargas. Os conceitos predominantes, durante o governo de Vargas eram de proteção, de conservação e de preservação apontando conceitos de que a natureza era entendida segundo duas linhas teóricas. enquanto conjunto de recursos econômicos, que poderia ser explorada racionalmente pensando no interesse das geraçôes futuras e enquanto diversidade biológica, objeto de ciência e de contemplaçáo estética, que deveria ser protegida. Durante a Conferência Brasileira de Proteção à Natureza ${ }^{55}$, nomes como os de José Bonifácio, Joaquim Nabuco, André Rebouças, Freire Alemão, Euclides da Cunha, Alberto Torres e Manoel Bonfim apareceram como referências, em função das críticas ao modelo das políticas ambientais brasileiras, pronunciadas por estas personalidades. Vários desses participantes já haviam apresentado suas consideraçóes referentes aos prejuízos das açóes humanas sobre o meio ambiente, no Brasil. As deliberaçóes da Conferência Brasileira de Proteção à Natureza, segundo Tavolaro (2000) foram, em parte, implementadas pelo governo Vargas que, até 1940, que esteve envolvido com o debate da preservação da natureza relacionada à identidade nacional. $\mathrm{O}$ autor ressalta ainda que, as recomendaçóes, do Governo Vargas, sobre o meio ambiente se orientaram pelas das deliberaçôes da I Conferência Brasileira de Proteção à Natureza ${ }^{56}$.

Durante os debates da I Conferência Brasileira de Proteção à Natureza, Franco (2002) destaca alternativas de proteçáo discutidas como os parques nacionais americanos que, além de promoverem a proteção, poderiam ser fonte de renda por meio da exploraçáo do turismo. A natureza como base para estudos científicos era reconhecida e havia o conhecimento de que aquele era um momento propício de mobilizar governo, universidade

53 Segundo Dean (1996) as legislaçôes anteriores apresentaram preocupaçôes ligadas aos ciclos de recursos visando apenas a demandas externas, nas quais os recursos naturais eram vistos apenas economicamente, negligenciando os impactos ambientais.

54 Segundo Franco (2002), a referida Conferência teve como objetivo reunir políticos e intelectuais para refletirem e formularem juntos propostas de políticas públicas que pudessem refletir e propor ao governo açóes que diminuíssem os avanços da destruição ambiental, buscando ganhos econômicos com o turismo.

55 Exposiçôes sobre o passado e iniciativas que estavam sendo aplicadas em outras regiōes do mundo foram apresentadas, visando fundamentar os argumentos a favor da proteção à natureza, conforme ressalta Sampaio (1935).

56 Segundo Tavolaro (2000) uma das recomendaçóes da Conferência apresentava o turismo como a melhor fórmula para a preservação da natureza, pois geraria divisas suficientes para a criação e manutenção de parques nacionais em todo o país, proporcionando empregos, sem abandonar a proteção do patrimônio natural. 
e outras lideranças defensoras da proteção ambiental, cujo foco seria a reverência à natureza, como fonte de apreciação estética e espiritual ${ }^{57}$.

A preservação de bens culturais, segundo o IPHAN (2019) tem sua importância discutida em âmbito nacional e internacional e é tema recorrente em várias esferas da sociedade brasileira, a partir das políticas públicas para a cultura como o Decreto-lei 25 de $1937^{58}$.

\subsection{A floresta na diáspora negra e a sua dimensáo patrimonial}

Autores como Cashmore et. al. (2000), no Dicionário de Relaçôes Étnicas e Raciais, convidam o leitor a uma reflexão sobre a elasticidade que o conceito de diáspora vem ocupando desde meados do século XX, contudo, esse alargamento do conceito pode, em alguns casos, inclusive comprometer sua aplicabilidade.

O referencial pertinente a esta pesquisa, teve como foco principal a sacralidade da floresta para as comunidades de Candomblé e usa o conceito de diáspora como resultante da experiência colonial ocasionada pelo tráfico negreiro, o ponto de partida para a constituição das relaçôes que às comunidades de Candomblé, como um subgrupo das comunidades tradicionais.

Diversas tradiçóes religiosas utilizam o meio ambiente como território para seus rituais. Uma diversidade de etnias indígenas e de matriz africana têm suas bases religiosas vinculada à natureza, onde se conectam com o sagrado. Esses territórios estão no entorno ou mesmo dentro do território de Unidades de Conservaçáo, Áreas de Preservação Permanente que possuem clareiras, rios, córregos, cascatas, lagos, cachoeiras, matas, montes e pedreiras, mas há que se destacar que o Candomblé59 reverencia a floresta em sua integralidade como habitat de um grupo de $\grave{O r}_{i} \dot{a}^{60}$ e, por isso, todo o seu território é sagrado. Esta tradiçấo cultural vê na Floresta um território sagrado, ideal para a comunicação e comunhão com suas divindades. O Candomblé, que segundo Barros (2011) reconhece a sacralidade da floresta, para a realização de oferendas como parte dos rituais praticados e local culto de suas divindades.

57 Nessa perspectiva, Pelegrini (2006) desta que desde meados do século XIX, a concepção de proteção ao "mundo selvagem" propiciou, a criação de parques e estaçôes ecológicas inspirados nos modelos norteamericanos, para os quais o uso deveria ser restrito.

$58 \mathrm{O}$ tombamento e/ou registro de áreas naturais são alternativas para que remanescentes florestais sejam protegidos.

59 Religião brasileira, que surge como herança cultural, religiosa e filosófica trazida pelos africanos escravizados, sendo aqui reformulada para poder se adequar e se adaptar às novas condiçóes ambientais (Kileury e Oxaguiã, 2009, s/p.).

60 Os Òrisà, Segundo Verger (2002) são ancestrais africanos que foram divinizados, mantendo uma inseparável ligação com os seres humanos. Segundo Pierre Verger, o Òrìà é uma forma pura, axé imaterial, que se torna perceptível aos seres humanos incorporando-se a um deles. 
No Candomblé divindades e elementos da natureza (fogo, água, terra, ar) em todas as suas derivaçóes, como raio, chuva, rio, praia, mar, lagoa, floresta, pedreiras, alimentos, folhas, e outros elementos da natureza, não há separação. Como observa Drummond (1997), nesse sentido, atribui-se a diferentes ambientes e paisagens simbolismos e significados, em especial por religióes e culturas, que valorizam alguns territórios por serem dotados de valores distintos daqueles considerados terrenos.

Para as comunidades de Candomblé, todos os elementos do ambiente natural trazem consigo, ao mesmo tempo, valores de uso e valores sagrados, materiais e simbólicos. Segundo destaca Scotto \& Limoncic (1997) entre esse grupo cultural e o poder público há o conflito de interesses, pois, o meio ambiente tem significados distintos para cada um deles.

Nessa perspectiva, os diferentes atores sociais passam, entâo, a disputar a natureza e os investimentos públicos que lhes garantam o acesso a esses territórios. Nesse processo de disputa, segundo Morais (2018) residem os conflitos por espaços nos territórios comuns que são utilizados para práticas diferentes, como é o caso dos remanescentes florestais.

A relação homem/natureza acontece em diferentes dimensôes e, para o Candomblé, uma dessas dimensōes, segundo Vieira Alves et. al. (1997) é a sagrada, que pode acontecer de diversas maneiras: por meio de cânticos, preces, danças, vivências, rituais e oferendas.

A realização de rituais tem, como um dos objetivos, a comunicação dos praticantes do Candomblé com suas divindades, e essa prática, quando realizada na natureza, é o reconhecimento do território como o espaço ideal para que essa comunicaçáo se dê de forma plena, por se tratar de ambientes nos quais residem a essência dos Òrisà, com todo o seu $\grave{s} s e^{61}$. Esse àse é relacionado à presença da vida e está presente no meio ambiente natural, o que segundo Barros (2011) transforma esse ambiente em território sagrado. Seguindo essa linha conceitual, Egler (2002) apresenta a floresta como o espaço onde são realizados os rituais do Candomblé pode ser interpretada como o território no qual uma diversidade de processos materiais e/ou imateriais são realizados. Esses locais onde as comunidades de Candomblé realizam seus rituais são permeados de conteúdos simbólicos e são identificados como espaços naturais sagrados, espaços santuários, sítios sagrados, lugares propícios para o contato com os seres da criação e para realização de práticas religiosas.

No entanto, em muitos casos, esses espaços sagrados estão em áreas naturais protegidas, como os Parques Nacionais ${ }^{62}$. Nessa perspectiva, observa-se alguns conflitos, o que segundo Egler (2002), pode evidenciar lacunas nas estratégias de proteção das florestas, a garantia de acesso público, o que consequentemente, interfere diretamente nas práticas religiosas realizadas no meio ambiente.

61 Àse significa força, poder, energia vital (Caputo, 2012, p. 72).

62 Ambientes naturais com relevância por seus aspectos ecológico, cênico, científico, cultural, educativo e de lazer, de acordo com o que aponta as ações preservacionistas de grupos brasileiros, bem como a legislação pertinente, como o Código Florestal Brasileiro aprovado em 2012. 
O processo de ocupação do território brasileiro até meados do século XIX, segundo Dean (1996) acontecia prioritariamente na faixa litorânea, fazendo com que o bioma da Floresta Atlântica fosse severamente impactado por ações antrópicas ${ }^{63}$.

Originalmente a cobertura vegetal do estado Santa Catarina era inteiramente dominada pela floresta atlântica. Contudo, entre o período de 1985 a 1990, a fragmentação florestal alcançou o maior patamar, com 19.882 hectares de florestas eliminadas. Atualmente, a taxa de desflorestamento em Santa Catarina tem sido controlada e, conforme avaliação da SOS Mata Atlântica (2012), uma média de 672 hectares entre os anos de 2012 e 2013 foram suprimidos. Grande parte dos remanescentes florestais, especialmente aqueles em que são observados cultivos intensos, Viana (1990) destaca que são encontrados como fragmentos, marcadamente perturbados, isolados, desconhecidos e desprotegidos. Os fatores que afetam incisivamente a dinâmica desses fragmentos florestais, segundo Melo Jr. et al. (2017), são o tamanho, a forma, o nível de isolamento, a qualidade, o tipo de vizinhança, e ainda o histórico de perturbaçóes, que na regiáo de Joinville pode ser observado nos intensos desmatamentos praticados até meados dos anos de 1990, ocasionados, principalmente, pela expansão da cidade, acompanhado pela especulação imobiliária com a anuência do poder público, situaçáo que tem se agravado porque as áreas florestais mais significativas, em extensão são de propriedade privada, no caso específico de Joinville, de propriedade das indústrias, especialmente do setor madeireiro (JOINVILLE, 2019).

A Mata Atlântica é, desde 1999, considerada Patrimônio Natural Mundial pela Unesco, que busca por meio desse reconhecimento oficial possibilitar a proteção das florestas primárias, bem como garantir a permanência do patrimônio étnico e cultural que circunda ou está no interior dessas áreas representado, especialmente, pelos povos originários e as comunidades tradicionais de matriz africana. Segundo apresenta o IPHAN (2019), os conhecimentos dessas comunidades sobre plantas medicinais, manifestaçóes rituais e artísticas para os quais os recursos naturais fornecidos pela floresta são imprescindíveis, podendo ser extintos, caso as florestas não sejam preservadas.

No Brasil, a terra é dividida em duas categorias: privada $^{64}$ e a pública ${ }^{65}$ e conforme ressalta Little (2002) o usufruto particular das terras públicas se converte em uma luta pelo controle do aparelho estatal ou, pelo menos, pelo direcionamento de suas açóes.

63 Segundo a SOS Mata Atlântica (2019) entre as principais consequências, das açôes antrópicas é possível observar a redução da cobertura original em áreas relictuais que, somadas, atingem a marca de $8 \%$ da extensão original, - desse total, $50 \%$ são de matas primárias e $50 \%$ secundárias.

64 Segundo Brito (2000) as terras públicas são aquelas regidas de acordo com os pressupostos teóricos do capitalismo, e o proprietário mantém o direito e o controle exclusivo, com direito da sua exploração para fins econômicos, de vendê-la e de reivindicá-la judicialmente caso ela esteja injustamente em poder de outrem.

65 Segundo Brito (2000) as terras públicas são associadas diretamente ao controle estatal. Segundo essa concepção, a terra é de propriedade dos cidadãos do país, contudo são as políticas públicas que definem seus usos. 
Para a presente pesquisa interessa a percepção das comunidades de Candomblé de Joinville, como um subgrupo das populaçôes tradicionais, conceituadas pela Constituição Federal de 1988 e descrita por Diegues (1996), baseadas em um conjunto de regras e valores consuetudinários, da "lei do respeito", e de uma teia de reciprocidades sociais fortalecidas pelo Decreto 6.040/2007.

Para as comunidades de Candomblé, há formas diferenciadas de apropriação da terra, que devem ser estruturadas, conforme os usos, significados e conhecimentos da natureza. É a partir das afinidades de cada família - que, no caso do Candomblé, não é definida pela consanguinidade - com determinada área em particular onde são criados territórios, que são incorporados à sua tradição, como acontece nos $i l e^{66}$, nos quais o controle da terra e seus recursos é familiar e social, fundamentados na afiliação por parentesco, no caso, da família de àse. Sendo assim, a posse é regida por regime de propriedade comum, respeitadas as hierarquias religiosas tradicionais. Nos ilé mais antigos, ainda hoje é assegurado um lugar para construir moradia nas suas dependências, aos iniciados que desejarem e/ou se for preciso, como ressalta Morais (2018) reproduzindo-se a territorialidade das aldeias africanas.

Para além dos espaços dos ilé, todos os ambientes naturais são territorialidades para as comunidades de matriz africana, pois toda a natureza é considerada sagrada, onde os elementos e paisagens são relacionados às divindades/Òrisà, que pode ser uma estrada, um lugar, uma pedra/pedreira, paisagem, planta, erva ou outro elemento/símbolo natural. Dessa forma, a natureza, segundo as comunidades de Candomblé, se encontra carregada de afetividade e significados, sendo portadora de simbologias e significados simbólicos. A natureza é reinterpretada pelas comunidades do Candomblé, conforme a tradição de matriz africana, como território que assume, conforme destaca Barros (2011), a função de pertencimento e identidade que o transforma em um espaço sagrado.

Nesse território sagrado "natureza", seus bens são coletivos e de uso comum, desde que observados as regras e os limites culturalmente preestabelecidos pelos sacerdotes, segundo suas interpretações da tradição. A apropriação da natureza, o acesso e o uso dos recursos ambientais são tratados como bens de interesse da coletividade e devem ter seus limites respeitados. Segundo Parajuli (2000), as comunidades de matriz africana reconhecem e respeitam a terra fazendo, seus rituais dentro do possível em suas áreas particulares. No entanto, as comunidades de matriz africana são possuidoras de uma razão histórica diferente da lógica instrumental do Estado ocidental brasileiro que, diante da instituição de áreas protegidas e muitas vezes demarcadas e destinadas a esse povo, ainda profere ameaças de desterritorialização, categorizando-os em uma nova modalidade: os povos afetados/atingidos por áreas protegidas.

A importância da floresta para o Candomblé dá-se por se tratar do território que formata suas identidades culturais, transformando-se naquilo que Zaqual (2006) chama de Sítios Simbólicos de Pertencimento. A identificação de lugares sagrados para as comunidades

66 Na nação Yorùbá, as casas de Candomblé denominam-se Ilé Àse, Terreiro ou Roça (Kileury; Oxaguiã, 2009, $\mathrm{s} / \mathrm{p})$. 
de Candomblé representa, segundo Barros (2011) importante forma de qualificar um espaço, dotando-o de sentimento e significado, transformando-o em uma espécie de templo.

Assim, conforme destacam Barros (2011) e Verger (1995), a valorização da floresta é uma função direta do sistema de conhecimento ambiental dos adeptos do Candomblé e suas respectivas tecnologias, incluídas aqui as tecnologias sociais/culturais. Todo conhecimento no Candomblé tem na oralidade sua principal forma de transmissáo de àse, o poder, a força das palavras, a energia vital que se acredita sem efeito em um texto escrito, pois é preciso a voz, o hálito das pessoas. Para que palavras possam efetivamente gerar energia —àse —, elas precisam ser pronunciadas e não necessariamente escritas.

Os terreiros de Candomblé são templos religiosos nos quais áfricas míticas são edificadas e como ressalta Barros (2011), talvez seja o melhor exemplo de originalidade que a diáspora produziu, possibilitando a continuidade da memória afrodescendente. O território/terreiro, segundo Santos (2008) é dividido entre e o "espaço urbano", onde estão as edificaçóes utilizadas para rituais e residências, e o "espaço mato", onde são plantados os elementos vegetais imprescindíveis ao culto. O "espaço mato", na maioria dos terreiros, ultrapassa os limites físicos e vai ao encontro das reservas naturais, ainda livres da urbanizaçáo, ocupando a cidade de forma geral, onde diversos cultos sáo ressignificados, tentando se aproximar dos rituais outrora praticados no continente africano.

Tendo o "espaço urbano", de certa forma, mais facilmente assegurado, o "espaço mato", em especial a extensão que ultrapassa os limites dos terreiros, tem sido cada vez mais difícil de assegurar, devido ao desenvolvimento e crescimento das cidades e da população. $\mathrm{O}$ desenvolvimento do capitalismo levou a maioria das sociedades ocidentais ditas civilizadas ao fenômeno da globalização e aos seus desdobramentos no século XXI, com o crescente processo de urbanização, o inchaço populacional e as consequências que isso provoca, à tecnologia como processo de desenvolvimento industrial, o transporte e tudo que o envolve, desde a prestação de serviços públicos de qualidade até a necessidade de abertura de vias públicas, acabam interferindo na dinâmica de proteçấo da floresta, táo importante para a manutenção dos rituais do Candomblé. Reside nesse paradoxo, como aponta Velho (1997) o desafio tanto intelectual quanto político em como conciliar a memória social, o patrimônio cultural e o patrimônio natural.

Para a prática do Candomblé é importante a organizaçáo social do espaço e das memórias, de forma que a dinâmica entre as identidades individuais e sociais estejam em equilíbrio. Segundo Halbwachs (1990), o início da rememoração pode apresentar abstraçóes, que se formam por meio de imagens ou de lembranças vivas que continuam existindo como prática. Tais possibilidades dependem de elementos que os estabelecem como grupos de referência. A lembrança, para esse autor, é o reconhecimento de açóes passadas, que são reconstruídas constantemente. Assim, a memória não é apenas a repetição contínua de algo que já aconteceu e é utilizada como forma a atender interesses contemporâneos.

Desde 1945, a UNESCO é segundo Arantes (2009) o centro mundial de referência para a elaboração de referências de técnicas conceituais de preservação e coordenadora do fórum que organiza e encaminha a celebração de acordos multilaterais sobre a temática. O autor ressalta ainda, que foi a Convenção de 1972 um dos marcos referenciais para as políticas de proteção do patrimônio ambiental, quando apresenta as recomendaçóes para a 
proteção do Patrimônio Mundial Cultural e Natural, tendo a universalidade como ponto de partida para o reconhecimento de seu valor cultural.

A referida Convenção de 1972, junto à Declaração Universal sobre a Diversidade Cultural de 2001 legitimam o valor dos bens culturais de natureza imaterial para os diferentes grupos sociais (ARANTES, 2009; IPHAN, 2019), sendo dois documentos internacionais que dialogam com o Art. 216 da Constituição Federal de 1988 (Brasil, 1988) e que atendem aos interesses dessa pesquisa qual seja, a floresta como patrimônio natural, cultural e espaço sagrado do Candomblé. O fato de terem os africanos transplantado um complexo sistema de classificação vegetal de origem africana necessário aos cultos de Candomblé à flora natural do Brasil, partindo de uma visão empírica ancestral, ampliou ainda mais seus conhecimentos sobre o mundo natural. Corrobora com a discussão Barros (2011), quando destaca que, o conhecimento das comunidades tradicionais de matriz africana deveria estar presente na formulação de políticas públicas que valorizasse e difundisse esses conhecimentos não só ritualísticos, mas também que serviriam de base para pesquisas na área da medicina. Sendo assim esses saberes e fazeres das comunidades de Candomblé, são também importante patrimônio cultural brasileiro, mesmo que ainda não haja um reconhecimento oficial.

Os conceitos de memória apresentados por Assmann (2016) estão em consonância com o conceito de Halbwachs (1990), quando afirma que a memória pode ser recente, mas o indivíduo compartilha com seus contemporâneos, como é comum no Candomblé, em que os mais velhos ensinam os mais novos, por meio dos itans ${ }^{67}$, ofó ${ }^{68}$ e òriki $i^{69}$, os valores e princípios ancestrais herdados dos ancestrais africanos. Essa prática é uma constante transmissão e ressignificação de passado, buscando manter no presente a cultura e a fé que atravessou o Atlântico no durante a escravidão. No Candomblé, a memória é fundamental por estar vinculada às tradiçóes, transmissóes e transferências como práticas cotidianas. Um aspecto importante da memória e da oralidade das comunidades de Candomblé pode ser destacada na existência de sacerdotes especialistas em tratar e manter a saúde, a partir do uso de folhas, realização de oferendas e rituais que são realizados na floresta, como destaca Barros (2011).

Entende-se a oralidade não como uma contraposição à escrita, mas como outra opção de registro e transmissão de conhecimento. O autor Bonvini (1981) afirma que a tradição oral vai além de um conjunto de textos orais e ultrapassa os limites do indivíduo. Ainda segundo o autor, a tradição oral africana é diferente das histórias fictícias do mundo ocidental por estar vinculada à experiência e à iniciação, buscando cotidianamente entender o homem em sua totalidade, sendo cultivada pelos africanos e seus descendentes, no Brasil, representados pelos ilé como território imprescindível à sua existência. Assim, observa-se a

67 Palavra Yorùbá que significa história, conto. (PÓVOAS, 2004).

68 São palavras ou pequenos versos que produzem o encantamento necessário para sacralizar os elementos, objetos ou instrumentos utilizados no candomblé. Com o ofó, extrai-se de simples ervas as propriedades sagradas e/ou terapêuticas e dá-se vigor e vibração aos objetos do cotidiano da religião (Kileury e Oxaguiã, $2009, \mathrm{~s} / \mathrm{p})$.

69 São rezas ou louvaçôes, em forma de versos ou poemas (Kileury e Oxaguiã, 2009, s/p). 
imprescindível presença da floresta para as comunidades de Candomblé, não só do ponto de vista religioso, mas também como recursos para a medicina alternativa, que busca a promoção do bem estar físico, social e mental, não só dos integrantes dos terreiros, mas de todos que lá buscam auxílio, como observa Barros (2011).

Mesmo com as dificuldades, devido à grande extensão territorial e a congregação de várias etnias, a tradição oral africana, no Brasil não é um resíduo feito de descontinuidades. Ela carrega em si, segundo Hampatê Bâ (2010), os traços estáveis da tradição oral africana, resistindo às dinâmicas do espaço e tempo, permanecendo viva nos ilé.

É importante para a análise das narrativas das comunidades de Candomblé, observar o que está na memória de cada integrante, de cada ilé, analisando o que esses documentos propóem, segundo Benjamin (1994), como uma tentativa de proteger e transmitir as lembranças fundamentais da civilização africana, a partir da concepção de ancestralidade que sustenta essas comunidades na diáspora.

Segundo apontamentos de Benjamin (1994), a narrativa como a arte de dar conselhos a partir da sabedoria acumulada pela experiência seria extinta pela dinâmica da vida moderna, nesse sentido Evaristo (2001) se vale dos conceitos benjaminianos sobre memória, narrativa e tradição oral para apresentar como essa arte de transmitir conhecimento sobrevive nos ilé, no mundo contemporâneo, como uma sociedade apartada dos princípios da sociedade industrial, que foi o foco dos estudos benjaminianos. Para Evaristo (2001), a oralidade continua viva nos ilé transmitindo e produzindo novas narrativas evidenciando sua pluralidade e diversidade. Nos ilé, se escuta com prazer sacerdotes e sacerdotisas que, muitas vezes, saem pouco daquele território, mas conhecem suas histórias, suas origens e as tradiçóes dos seus ancestrais, inclusive dos Òrisà, e no Candomblé, assim como descreve Benjamin (1994), parte significativa da arte narrativa está em apresentar uma história evitando explicaçóes: o destaque é para informação que contém.

A prática da oralidade não é aqui entendida como a conservação e o armazenamento de depoimentos, mas sim como uma maneira de produzir fontes históricas abertas a novas propostas, possibilidades e significaçóes. Tais narrativas mantêm vivas as histórias daqueles africanos que não tiveram tempo de trazer consigo nenhum bem material, nenhum objeto pessoal que o vinculasse à sua pátria e à sua terra. Segundo Evaristo (2011) valorizar a ancestralidade de matriz africana é manter viva a memória de quem trouxe apenas suas lembranças guardadas na memória. Nos terreiros de Candomblé, a herança africana é viva e pode ser observada nas formas de intercambiar experiências por meio de narrativas — cada vez mais raro no século 21 , nas sociedades ocidentais, ditas civilizadas - elevando sua importância e destacando sua ausência fora desses territórios.

A memória retrata a importância fundamental das narrativas para as comunidades de Candomblé, pois ela é o que une passado/presente/futuro e, sem ela, não há identidade do grupo. Entende-se o Candomblé como prática cultural que resiste na diáspora, e esse grupo pode ser enquadrado no conceito de memórias fortes, como apresenta Candau (2011) que busca criar marcas sólidas, visando reforçar sentimentos de origem, historicidade e pertencimento, se distanciando das memórias fracas, que se diluem e fragmentam de acordo com que as identidades se transformam, conformando novas identidades. Para as comunidades de Candomblé, perder a memória seria o mesmo que perder a identidade. 
Nesse sentido, o acesso à floresta, segundo Barros (2011), a utilização da floresta tanto como fonte de recursos como território sagrado, foi no passado uma forma de resistência cultural e, atualmente, pode ser interpretada como um legado cultural dos afro-brasileiros e uma forma de fortalecimento e reconexão com sua ancestralidade africana.

\section{Conclusáo}

Percebeu-se ao longo da pesquisa que o conceito de patrimônio natural e cultural consagrado na Constituiçáo Federal de 1988 pode ser interpretado como grande avanço ao reconhecer a dimensão imaterial, por possibilitar a relativização da noção de excepcionalidade e pensar a partir da representatividade, destacando as contribuiçóes da diversidade cultural formadora da sociedade brasileira. $\mathrm{O}$ conceito de referência cultural torna-se presente no discurso estatal e significa uma importante ampliação dos bens suscetíveis de reconhecimento como patrimônio cultural, nas esferas nacional, estaduais e municipais, dos quais a floresta é o destaque dessa pesquisa. Contudo, a ausência das comunidades tradicionais, incluindo o Candomblé, é perceptível no debate e na formulação das políticas públicas referente à temática em questão.

A concepção de patrimônio natural, a partir da Convençáo do Patrimônio Mundial da Organização das Nações Unidas para a Educação, a Ciência e a Cultura (UNESCO) realizada em 1972, aponta para a possibilidade de se expandir o conceito de patrimônio cultural e natural, incluindo uma diversidade de experiências coletivas, entre as quais interpretamos incluir os relacionados à matriz africana, mas até o momento, mesmo com a criação do Sistema Nacional de Meio Ambiente/SISNAM e os conselhos nacional e locais não incluem as comunidades de tradicionais, dentro as quais destaca-se as comunidades de Candomblé. Percebe-se a relaçáo do patrimônio natural sob a ótica do cotidiano, sendo apropriado socialmente pelas comunidades de Candomblé, que entendem a natureza náo apenas como algo indispensável à vida humana, mas também como integrante da memória coletiva, das histórias vividas e de sua prática de fé, entendida como a dimensão sagrada do território florestal.

As políticas de proteção do patrimônio cultural, no mundo contemporâneo não mais se restringem ao âmbito do poder público, nem se esgotam na ação legal de tombamento ou dos inventários e registros em livros oficiais. Sua gestão implica não só em leis de proteção, mas em estratégias de valorização, que envolvem diferentes setores da sociedade como as comunidades de Candomblé e os gestores públicos.

As políticas de proteção do patrimônio cultural no mundo contemporâneo não mais se restringem ao âmbito do poder público, nem se esgotam na ação legal de tombamento ou dos inventários e registros em livros oficiais. Sua gestão implica não só em leis de proteção, mas em estratégias de valorização que envolvem diferentes setores da sociedade. Sendo assim, entendendo a floresta como território sagrado das comunidades de Candomblé, como se expressa a dimensão patrimonial da floresta a partir das percepçóes dessas comunidades? As comunidades de Candomblé despertam o interesse de pesquisadores nas temáticas do universo mágico, dos rituais, do culto e menos sobre a cosmovisão universal. 
Percebeu-se na literatura que há o sentimento de pertencimento e a uma tentativa de recriação do espaço florestal em seus ilé o que indica a importância de árvores, folhas e ervas para essas comunidades. Observa-se a descrição de práticas rituais que são realizadas fora dos espaços privados do ilé, destacando observaçóes de que há a necessidade de irem à floresta e/ou outros territórios naturais. Essas descriçóes indicam que essas comunidades podem contribuir para a categorização da floresta como patrimônio natural e cultural, por meio da evidência da memória e expressão da diversidade da sociedade. A floresta, nesse caso, pode ser entendida como paisagem habitada por diferentes Orisà e espaço que garante ao grupo o direito de criar, produzir e usufruir desse território.

Nesse sentido, destaca-se que poucas publicaçóes se dedicaram à pesquisas sobre como as comunidades de Candomblé interpretam a floresta além da perspectiva utilitária e/ou econômica e a veem como território sagrado, onde vivem as divindades ancestrais que cultuam, onde realizam rituais e coletam folhas importantes para os cultos que realizam em seus templos.

A pesquisa bibliográfica aponta que, há poucas pesquisas sobre os movimentos das comunidades de Candomblé que conformam redes de convivência e de troca de tecnologias entre si e com outros subgrupos das comunidades tradicionais visando proporcionar maior resiliência para as florestas e garantir seu acesso a esses territórios, ultrapassando os limites físicos dos ilé àse.

Assim, entendendo a floresta como território sagrado das comunidades de Candomblé, como se expressa a dimensão patrimonial da floresta a partir das percepçóes dessas comunidades? A bibliografia apontou para a ausência de publicaçôes sobre a compreensão das comunidades de Candomblé no que se refere à patrimonialização da floresta considerando os elementos sagrados desse território.

A grande maioria das publicaçóes refere-se aos aspectos relativos à memória, resistência da população negra e/ou os aspectos litúrgicos do Candomblé e que não são alvo dessa pesquisa. Acredita-se que a ocupação dos espaços públicos de debate é o que permitirá a reverberação dos conceitos e valores da matriz africana para a proteçáo das florestas como patrimônio cultural e natural, garantindo às comunidades de Candomblé a continuidade de suas práticas rituais nos territórios naturais.

\section{Agradecimento}

Os autores agradecem ao Programa de Pós-graduação em Patrimônio Cultural e Sociedade Universidade da Região Universidade da Regiāo de Joinville/SC pela concessão de bolsa à primeira autora.

\section{Referências}

AHRENS, S. O "novo" Código Florestal brasileiro: conceitos jurídicos fundamentais. In: Congresso Florestal Brasileiro. São Paulo: 2003.

ANTUNES, P. de B. Direito ambiental. Rio de Janeiro: Editora Lúmen Júris, 2000. 
ARANTES, Antônio A. Patrimônio Cultural e cidade. In: FORTUNA, Carlos, LEITE, Rogério Proença (Orgs.). Plural de Cidade: léxicos e culturas urbanas. Lisboa: Almedina, 2009.

ASSMANN, jan. Memória Comunicativa e Memória Cultural. Revista História Oral, v. 19, n. 1, p. 115-127, jan-jun, 2016.

BARROS, José Flávio Pessoa de. A floresta sagrada de Ossaim: o segredo das folhas. Rio de Janeiro: Pallas, 2011.

BEAUD, Michel. História do capitalismo de 1500 aos nossos dias. São Paulo: Brasiliense, 1989.

BENJAMIN, Walter. O Narrador. In: Magia e Técnica, Arte e Política - ensaios sobre literatura e história da cultura. Obras escolhidas, volume I, 2a edição, São Paulo: Editora Brasiliense, 1994.

BONVINI, Emilio. Traição Oral Afro-brasileira. As Razões de uma Vitalidade. In: Projeto História: Revista do Programa de Estudos Pós-Graduados em História e do Departamento de História da PUC-SP, n. 22. São Paulo: EDUC, 1981.

BOXER, Charles. O império marítimo português. São Paulo: Companhia das Letras, 2002.

BRASIL. Constituição Federal do Brasil. Constituição (1988). Constituição da República Federativa do Brasil, DF: Senado Federal: Centro Gráfico, 1988.

BRASIL. CONSTITUIÇÃO DOS ESTADOS UNIDOS DO BRASIL (1946).

Disponível em: <http://www.planalto.gov.br/ccivil_03/constituicao/constituicao46.htm>. Acesso em 20 fev. 2019.

BRASIL. Decreto lei 25/37. Organiza a proteção do patrimônio histórico e artístico nacional. Disponível em <http://www.planalto.gov.br/ccivil_03/decreto-lei/del0025.htm>. Acesso em 20 fev. 2019.

BRITO, Maria Cecilia Wey de. Unidades de Conservação: intenções e resultados. São Paulo: Annablume, FAPESP, 2000.

BURSZTYN, Marcel \& BURSZTYN Maria Augusta. Fundamentos de política e gestáo ambiental: os caminhos do desenvolvimento sustentável. Rio de Janeiro: Garamond, 2012.

CABRAL, Diogo de Carvalho. Na presença da floresta: Mata Atlântica e história colonial. Rio de Janeiro: Garamond, 2014. 
CAPUTO, Stela Guedes. Educação nos terreiros: e como a escola se relaciona com crianças de Candomblé. Rio de Janeiro: Pallas, 2012.

CARDIM, Fernão. Tratados da terra e gente do Brasil. São Paulo: Cia Editora Nacional, 1939.

CANDAU, Joel. Memória e Identidade. São Paulo: Contexto, 2011.

CASHMORE, Elis, BANTON, Michel et.al. Dicionário de relaçóes étnicas e raciais. São Paulo: Summus, 2000.

CORTESÃO, Jaime. A carta de Pêro Vaz de Caminha. Lisboa: Portugália, 1967.

COUTO Jorge. A Construçáo do Brasil Ameríndios, portugueses e africanos - do início do povoamento a finais de quinhentos. Lisboa: Ediçóes Cosmos, 1997.

DEAN, Warren. A Ferro e Fogo - A História e a Devastação da Mata Atlântica Brasileira. São Paulo: Cia das Letras, 1996.

DIEGUES, A. C. O mito moderno da natureza intocada. Sáo Paulo: Ed. Hucitec, NUPAUB, 2008.

DIEGUES, Antônio Carlos. Repensando e recriando as formas de apropriação comum dos espaços e recursos naturais. In: VIEIRA, P. F.; WEBER, J. (Orgs.). Gestáo de recursos naturais renováveis e desenvolvimento. São Paulo: Cortez Editora, 1996.

DIEGUES JR., M. Regióes culturais no Brasil. Rio de Janeiro: MEC, INEP, Centro Brasileiro de Pesquisas Educacionais (Publ. CBPE, série 6, Sociedade e Educação 2), 1960.

DINIZ, Mônica. Sesmarias e posses de terras: política fundiária para assegurar a colonização brasileira. Revista Eletrônica do Arquivo do Estado de Sáo Paulo. Edição no 2 de junho, 2005.

DRUMMOND, José Augusto. Devastação e Preservação Ambiental no Rio de Janeiro: os parques nacionais do Estado do Rio de Janeiro. Niterói: EDUFF, 1997.

EGLER, Tamara Tania Cohen. Exclusão e inclusão na sociedade do conhecimento.

Cadernos IPPUR/UFRJ, 2001/2, 2002/1

EVARISTO, Conceição. Mãe Beata de Yemonjá. In: DUARTE, E. de A.; FONSECA, M. N. S. (Orgs). Literatura e Afrodescendência no Brasil: antologia crítica. Belo Horizonte: Editora UFMG, 2011, 2 v., p. $31-42$.

FELDENS, Leopoldo. O homem, a agricultura e a história. Lajeado: Editora Univates, 2018. 
FERREIRA, Norma Sandra de Almeida. As pesquisas denominadas "estado da arte". Educaçáo \& Sociedade, Campinas, n. 79, p. 257-272, ago. 2002. Disponível em: <http://www.scielo.br/pdf/es/v23n79/10857.pdf>. Acesso em: 04 mai. 2020.

FRANCO, J. L. A. A primeira conferência Brasileira de Proteção à natureza e a questão da identidade Nacional. In: Varia História. Belo Horizonte: UFMG, 2002. Disponível em: <http://www.fafich.ufmg.br/varia/revista/index.php?prog=mostraartigo. php\&idcodigo=265>. Acesso em: 30 jan. 2019.

GONÇALVES, Carlos Walter Porto. Os (des)caminhos do Meio Ambiente. São Paulo: Contexto, 1990. p. 23.

HALBWACHS, Maurice. A memória coletiva. São Paulo: Vértice, 1990.

HAMPÂTÉ BÂ. "A tradição viva”. In: Ki-Zerbo, J. (Org.) História geral da África. São Paulo: Ática/UNESCO, 1982. p. 181-218.

HOLANDA, Sérgio Buarque de. Raízes do Brasil. São Paulo: Cia das Letras, 1995.

HUTTER LM. A madeira do Brasil na construção e reparo de embarcaçôes. Revista do Instituto de Estatística Brasileira 26: 47-64. São Paulo, 1986.

IBGE. Instituto Brasileiro de Geografia e Estatística/IBGE. Manual Técnico da Vegetação Brasileira: Sistema fitogeográfico Inventário das formações florestais e campestres Técnicas e manejo de coleçóes botânicas Procedimentos para mapeamentos. Rio de Janeiro: IBGE, 2012.

IPHAN. Patrimônio Natural no Brasil. Rio de Janeiro: IPHAN, 2007. Disponível em <http://portal.iphan.gov.br/uploads/publicacao/Patrimonio_Natural_no_Brasil.pdf>. Acesso: 10. jan. 2019.

IORIS, Edviges, Marta. Uma floresta em disputa: conflitos sobre espaços, recursos e identidades sociais na Amazônia. Florianópolis: UFSC, 2014.

JOINVILLE. Plano Municipal de Conservaçáo e Recuperação da Mata Atlântica. Joinville: Secretária de Agricultura e Meio Ambiente, 2018, $1^{\text {a }}$ versão. Disponível em: <https://www.joinville.sc.gov.br/wp-content/uploads/2019/04/Plano-Municipal-deConservação-e-Recuperação-da-Mata-Atlântica-PMMA-2018.pdf>. Acesso: 10 jan. 2019.

KILEURY, Odé; OXAGUIÂ, Vera de. O candomblé bem explicado: Nações Bantu, Iorubá e Fon. Rio de Janeiro: Pallas, 2014.

LÉRY Jean de. Viagem à Terra do Brasil. Rio de Janeiro: Bibliex, 1972.

LIMA, Anielly Iasmin Nunes; CRUZ, Caio Borba; SILVA, Érica De Lima. Impactos Provocados no Meio Ambiente Pelo uso da Madeira na Construção Civil. Revista 
Científica Multidisciplinar Núcleo do Conhecimento. Edição 03. Ano 02, Vol. 01. pp 116-135, junho de 2017. São Paulo. Disponível em: <https://www. nucleodoconhecimento.com.br/>. Acesso: 23 jul. 2019.

LIMA, Vivaldo da Costa. A Família de Santo nos Candomblés Jêjes-nagôs da Bahia: um estudo de relações intragrupais. 2 ed. Salvador: Corrupio, 2003

LITTLE, Paul E. Territórios Sociais e Povos Tradicionais no Brasil: por uma antropologia da territorialidade. Serie Antropológica n ${ }^{\circ} 322$. Brasília: Departamento de Antropologia, Instituto de Ciências Sociais, UNB, 2002.

LUSTOSA, M. C. J.; CÂNEPA, E. M; YOUNG, C. E. F. Política ambiental. In: MAY, P.; LUSTOSA, M. C.; VINHA, V. Economia do meio ambiente: teoria e prática. Rio de Janeiro: Elsevier, 2003.

MAGALHÃES, J. P. Evolução do direito ambiental no Brasil. São Paulo: Ed. Juarez de Oliveira, 2002.

MARTIN, Pedro Tomé. Dioses, hombres, animales y plantas em la etnología Ameríndia. In: BARRIO, Ângel B. Espina (Dir). Antropología em Castilha Y León e Iberoamérica: Aspectos generales y religiosidades populares. Dirección general de Universidades e Investigación Junta de Castilha y León, Salamanca 1998.

MELlO, Evaldo Cabral de. O Bagaço de Cana. São Paulo: Penguin \& Companhia das Letras, 2012. Pág. 76.

MELO Jr., et al. Flora vascular, estrutura comunitária e conservação de fragmentos da floresta atlântica na Bacia Hidrográfica do rio Cachoeira, Joinville, SC, Brasil. ACTA BIOLÓGICA CATARINENSE, v. 4, p. 41-72. Joinville, 2017.

MILARÉ, Édis. Direito do Ambiente - Doutrina - Jurisprudência - Glossário. 2a ed., São Paulo: Revista dos Tribunais, 2001.

MORAIS, Hugo Arruda de. Território e territorialidades: dimensóes constitutivas da relação homem e meio ambiente. Revista Brasileira de Geografia Física v.11, n.01 (2018) 206-222. [S.1.], v. 11, n. 1, p. 206-222, fev. 2018. Disponível em: <https:// periodicos.ufpe.br/revistas/rbgfe/article/view/234309>. Acesso em: 30 maio 2019.

OLIVEIRA, Érica Beatriz Pinto Moreschi. Periódicos científicos eletrônicos: definiçóes e histórico. Inf. \& Soc.:Est., João Pessoa, v.18, n.2, p. 69-77, maio/ago. 2008

ORGANIZAÇÃO DAS NAÇÕES UNIDAS. Agricultura e alimentaçáo/FAO.

Disponível em:<http://www.fao.org>. Acesso: 20 jan. 2019.

PÁDUA, José Augusto. Ecologia no Brasil. Rio de Janeiro: Espaço e Tempo/IUPERJ, 1987. 
PARAJULI, Pramod. Retornando ao lar Terra: Etnicidades ecologicas e diversidades bioculturais na idade da ecologia. In HERCULANO, S. \& PACHECO, T. (orgs). Racismo Ambiental. [Anais...] I Seminário Brasileiro contra o Racismo Ambiental. São Paulo: Annablume/FAPESP, 2000.

PELEGRINI Sandra C. A. Cultura e natureza: os desafios das práticas preservacionistas na esfera do patrimônio cultural e ambiental. Revista Brasileira de História. São Paulo, v. 26, no 51, p. 115-140 - 2006. Disponível em: <http://dx.doi.org/10.1590/S0102$01882006000100007>$. Acesso em 10 jan. 2019.

PEREIRA, Osny Duarte. Direito Florestal Brasileiro. Rio de Janeiro: Borsoi, 1950.

PÓVOAS, Ruy do Carmo. Itan dos mais-velhos: contos. Ilhéus: Editus, 2004.

PRANDI, Reginaldo. O Brasil com axé: candomblé e umbanda no mercado religioso. Estudos Avançados 18 (52). São Paulo: IEA-USP, 2004

REBOUÇAS, A. C. Recursos hídricos subterrâneos da Bacia do Paraná: Análise de pré-viabilidade. Tese de Livre Docência. Geologia Econômica e Geofísica Aplicada Instituto de Geociências da Universidade de São Paulo, 1976. Disponível em: <http:// www.teses.usp.br/teses/disponiveis/livredocencia/44/tde-02062014-141431/pt-br.php>. Acesso: 20/12/2018.

ROMANOWSKI, Joana Paulin; ENS, Romilda Teodora. As pesquisas denominadas do tipo "Estado da Arte" em Educação. Diálogo Educacional, Curitiba, v. 6, n. 19, p. 37-50, dez. 2006. Disponível em: <http://www2. pucpr.br/reol/pb/index.php/ dialogo?dd $1=237 \& d d 99=$ view $\&$ dd $98=$ pb $>$. Acesso em 04 mai. 2020

RONCÁGLIO, Cynthia. A ideia da natureza como patrimônio: um percurso histórico. In: Desenvolvimento e Meio Ambiente, n. 19, p. 111-128, jan/jun. 2009. Editora UFPR, Curitiba, Paraná.

SALVADOR, Frei Vicente do. História do Brasil - 1550/1627. São Paulo: Weisflog Irmãos, 1918.

SAMPAIO, Alberto José. Relatório Geral da Primeira Conferência Brasileira de Proteção à Natureza. In: Boletim do Museu Nacional, vol. XI, nº 1, março de 1935.

SANTOS, Juana Elbein dos. Os Nagô e a Morte: Pàde, àsèsè e o Culto Égun na Bahia. Petrópolis: Vozes, 2008.

SCHÄFFER, Wigold. PROCHNOW, Miriam (orgs.). A Mata Atlântica e Você - Como preservar, recuperar e se beneficiar da mais ameaçada floresta brasileira. Brasília: Apremavi, 2002. 
SCOTTO, Gabriela e LIMONCIC, Flavio (Org). Conflitos Sócio-Ambientais no Brasil: O caso do Rio de Janeiro. Vol. II. Rio de Janeiro: Projeto Meio Ambiente e Democracia, IBASE e Fundação Heinrich-Boll, 1997.

SÉGUIN, Élida \& CARRERA, Francisco. Lei dos Crimes Ambientais. Rio de Janeiro: Adcoas, 1999.

SOS Mata Atlântica, 2019. Atlas dos Remanescentes Florestais da Mata Atlântica. Disponível em<https://www.sosma.org.br/projeto/atlas-da-mata-atlantica/> Acesso; 06 mai. 2019.

TAVOLARO, Sergio B. F. Sociabilidade e construção de identidade entre antropocêntricos e ecocêntricos. In: Ambiente \& Sociedade. Ano III, no 6/7, $1^{\circ}$ Semestre de 2000/2o Semestre de 2000 pp. 63-84. Disponível em: <http://www.scielo.br/pdf/asoc/ n6-7/20427.pdf>. Acesso em: 10. Jan. 2019.

VERGER, Pierre. O Olhar viajante de Pierre Fatumbi Verger. Salvador, Fundação Pierre Verger, 2002.

VERGER, Pierre Fatumbi. Ewé: o uso das plantas na sociedade iorubá. São Paulo: Companhia das Letras, 1995.

VIANA, V. M. Biologia e manejo de fragmentos florestais. In: Congresso Florestal Brasileiro, 6, Campos do Jordão, 1990. [Anais....]. Curitiba: Sociedade Brasileira de Silvicultura/Sociedade de Engenheiros Florestais, 1990. p. 113-118.

VIEIRA, Ana Cristina P., ALVES, Denise et al. Meio Ambiente e Espaços Sagrados. [Anais...]. Curitiba: Congresso Brasileiro de Unidades de Conservaçáo, v. 1, 1997.

WAINER, na Helen. Legislação ambiental brasileira: evolução histórica do Direito ambiental. Revista de Informaçáo Legislativa, Brasília: Editora forense, 1991.

Disponível em <http://www2.senado.leg.br/bdsf/handle/id/176003>. Acesso em 02 dez. 2018.

ZAOUAL, Hassan. Nova economia das iniciativas locais: uma introdução ao pensamento pós-global. Rio de Janeiro: DP\&A: Consulado Geral da França: COPPE/ 